\title{
Nusantara Microalgae Park: Solution of Energy Crisis in Outer and Small Islands of Indonesia
}

\author{
Kaisar Akhira*, M. Imaad Al Hamas ${ }^{b}$ and Dwi Puspitasaric \\ a Marine Science and Technology Department, Bogor Agricultural University, Bogor, Indonesia \\ ${ }^{b}$ Naval Architecture and Marine Engineering, University of Indonesia, Depok, Indonesia \\ ${ }^{c}$ German Literature, University of Indonesia, Depok, Indonesia
}

\begin{abstract}
Indonesia is the largest archipelago country in the world that has strategic geographical position. Indonesia has about 13,466 islands that have been named, 5.8 million $\mathrm{km}^{2}$ sea areas and the fourth longest coastline in the world with a total length of $95,181 \mathrm{~km}$. Geographically, Indonesia is located in a strategic position of world cruise lines, between the continent of Asia and Australia and between Indian Ocean and Pacific Ocean. Indonesian archipelago has only 28 islands which are not classified as small islands. This fact shows that Indonesia has more than 13 thousands small islands and 92 islands which are the outer small islands. Outer and small islands are potentially for economic development and national defense. Therefore, the number of energy needs increases. To fulfill the energy needs in the form of bio-diesel and bio-kerosene, the marine microalgae is the great potential. Nusantara Microalgae Park is a concept of marine microalgae cultivation area based on coastal societies in outer and small islands. Bio-diesel and bio-kerosene produced from this concept will be very helpful for people in fishing and cooking environmentally friendly. This concept can be integrated with Island Adoption Program, Cooperative Program and Transmigration Program. To implement this concept so that sustainable, there are four principles (pro-poor, pro-job, pro-growth and pro-environment) and five pillars (economy, people, technology, academics and institutions coordination).
\end{abstract}

Keywords: marine microalgae, small islands, coastal community, biofuel, Indonesia, sustainable

\section{Introduction}

Indonesia is a rich marine and coastal resources potential country. Indonesia has 13,466 islands that have named (Directorate of Small Islands Utilization 2012), 5.8 million $\mathrm{km}^{2}$ sea area or about 70 percents of the total area of the country (Mawardi 2009) and the fourth longest coastline in the world after Canada, United States of America and Russia, with a total length of 95,181 km (Mukhtar 2009). Geographically, Indonesia is located in strategic position of world cruise lines, between Asian and Australian Continent and between Indian and Pacific Ocean. Beside that, Indonesia has also wealth of marine biological resources which are very abundant. According to Dahuri (2003) marine biodiversity in Indonesia is more than 9,500 species.
Indonesian archipelago has only 28 islands which are not classified as small islands (Island Directory UNEP inside Mawardi 2009). This fact shows that Indonesia has more than 13,000 small islands and 92 islands which are the outer small islands (Directorate of Small Islands Utilization 2012). 12 islands from 92 islands have received special attention because their border location with neighboring countries (Editorial Team 2004).

Outer and small islands are potentially for economic development and national defense. Outer and small islands that have strong energy security will also have an impact on strong national social security, economic security and politic security. Therefore the provision of energy sources in outer and small islands is very important and the energy resources that can be developed are marine microalgae. Marine microalgae

* Corresponding author: Tel: +62-8998227218
E-mail: kaisarakhir@ rocketmail.com

ISSN 2413-5453 @ 2015 The Authors.

Published by KnowledgeE Publishing Services. This is an open access article under the CC BY-NC-ND

license (http://creativecommons.org/licenses/by-nc-nd/4.0)

Peer-review under responsibility of EBTKE-CONEX 2013

DOI http://dx.doi.org/10.18502/ken.v1i1.326 
can be used as a source of bio-diesel and bio-kerosene. This provision in the form of system named Nusantara Microalgae Park. Thus the problem of energy crisis can be solved not only in the larger islands but also in small and outer islands.

\section{Method}

\subsection{Analysis of Problems}

Analysis of the energy crisis problems in outer and small islands in Indonesia are based on actual data and information which are associated with government policies in order to become reference material for the proposed solution strategy formulation.

\subsection{Formulation of Solution Strategy}

The proposed solution strategy is formulated based on the result of problems and potential analysis. The solution strategy is formulated in system named Nusantara Microalgae Park.

\subsection{Types and Sources of Data}

Type of data used in this study is secondary data and derived from the literature, such as books, journals, articles and statistic data related to the topic of discussion.

\subsection{Processing Methods}

The process of obtaining information and data through a qualitative-descriptive approach. Problem solving process was done by identifying problems, analyzing the factors causing the problem, then determining the solution of the problems with the analysis of the study on used data.

\subsection{Withdrawal Conclusions and Suggestions}

The final stage of this writing is withdrawal the conclusion of the discussion to generate the necessary suggestions in line with the proposed solution strategy.

\section{Result and Discussion}

\subsection{Strategic Role of Outer and Small Islands}

Outer and small islands in Indonesia have strategic role in national economic development and defense.

\subsubsection{Economic development}

Small islands have great potential for economic development with resource based industry (Mawardi
2009). According to Law of Republic of Indonesia No. 27 of 2007 on the Management of Coastal Areas and Small Islands, the definition of a small island is an island with an area of less than or equal to $2,000 \mathrm{~km}^{2}$ and its unity ecosystem. According to Mawardi (2009) and Dahuri (2005), economic activities based on the community that can conducted in the small islands are ecotourism, tourism, agro-industry, marine industry, fishing, marine aquaculture, mining, trade, sea transportation and marine energy management.

Utilization of small islands can reduce poverty and unemployment in Indonesia. Based on data from Badan Pusat Statistik Republik of Indonesia (2012), the poor in Indonesia amounted to 28,594,600 inhabitants in 2012 and the population with the status of unemployed amounted to 7,170,523 inhabitants in 2013 (Badan Pusat Statistik Republik of Indonesia 2013a). Through the transmigration program, cooperatives and adoption of the island as well as economic activity based on community, both these problems can be reduced, because the population being evenly distributed, have a job and increasing income.

However, the success of economic activities and government program can not be achieved without a strong energy security, because energy is primary needs of transportation, ligthing, production activity and cooking. The major types of fuel used by communities in small islands are diesel and kerosene for fishing, transportation and cooking.

The lack of economic development in Indonesia in past time is characterized by the absence of the Rupiah in two islands, Sipadan Island and Ligitan Island (Platmerah 2013) so that both were separated from Indonesia by International Court of Justice judgement's. This happened in 2002.

\subsubsection{Defense}

Outer small islands are important areas in national defense. Their existence determines the boundaries of the country, particularly territorial sea and exclusive economic zone. Since Nusantara (archipelago nation principle of Indonesia) declared on December 13, 1957, known as the Declaration Juanda, sea boundary territory of the Republic of Indonesia to 12 miles measured from the straight baseline connecting the outer points of the outer islands of the Indonesian archipelago. This declaration also get international recognition in United Nations Convention on the Law of the Sea 1982 (UNCLOS 1982). Besides territorial sea, 
Indonesia has also a sovereignty rights for the purposes of exploration, exploitation, conservation and management of natural resources, both biological and non-biological, of the waters above the seabed and of the seabed and soil beneath and with relate to other activities for the purposes of exploration and economic exploitation such as production of energy from water, currents and winds in the exclusive economic zone (Article 56 UNCLOS 1982). Exclusive economic zone (EEZ) is an area beyond and adjacent to the territorial sea, subject to the specific legal regime established by the rights and jurisdiction of the coastal state and the rights and freedoms of other countries (Article 55 UNCLOS 1982). EEZ width should not exceed 200 nautical miles from the line where the base width of the territorial sea is measured (Article 57 UNCLOS 1982). Therefore outer and small islands must be maintained and managed properly, including through the provision of sustainable energy sources.

Conflict in South China Sea is one of the cases that demanded Indonesia to have a strong defense and security of EEZ that originated from the island with strong defense.

\subsection{Analysis of Energy Crisis in Outer and Small Islands of Indonesia}

\subsubsection{Analysis of factors and impacts}

Has been for centuries Indonesian people depend on fossil fuels, including the people who live in outer and small islands. Petroleum reserves in Indonesia which has been proven in the range of 2010 to 2013 has decreased from 4.23 billion barrels (General Directorate of Oil and Gas 2011) to 3.59 billion barrels (Christina 2013). According to the Indonesian petroleum analyst, Dr. Kurtubi, owned petroleum reserves would be exhausted in Indonesia 12 years starting from the year 2012 (Pikiran Rakyat Online 2012).

Decline in petroleum reserves causes the difficulty in obtaining fuel. People in small islands have to wait to get a shipment of fuel. Worse, sometimes it did not reach the public because of rogue elements that stockpiled fuel. These are the real phenomena that happen. Therefore, the provision of energy fuels in outer and small islands should be realized without waiting the shipment of fuel coming, so that there is no more energy crisis.

Impacts of the energy crisis, such as: income and food supply is reduced due to the fishing and another economic activity is stalled; lighting to be reduced or dead; cooking activities and production also suspended or reduced.

\subsubsection{Analysis of government policies}

The government is currently intensifying the island adoption program to utilize small islands involving various stakeholders, including government, public and private. The program funding comes from fund corporate social responsibility (CSR) of private and state-owned company (General Directorate of Marine, Coastal and Small Islands 2011). The program emphasizes the development of society through its social aspects, without demanding profit and return on invested funds. Renewable energy sources development activities can be accomplished through this program.

In addition to the island adoption program, government also provided a program named "Solar Packed Dealer untuk Nelayan (SPDN)". Ministry of Maritime Affairs and Fisheries (MMAF) in Tempo (2013) said that it will build 1,000 units of SPDN in 2013 in the fishing centers in Indonesia such as fishing ports. The program is organized by the MMAF in cooperation with the Ministry of Energy and Mineral Resources and PT Pertamina (Persero). Until this time, the ministry has facilitated the construction of at least 291 units of SPDN in throughout Indonesia. However, according to the Ministry of Maritime Affairs and Fisheries, Sharif Cicip Sutardjo, in Tempo (2013), Indonesia must has at least 808 units SPDN, according to the number of existing fishing harbors. In addition, needs of diesel for fishermen is very important, because 60 percents of the production cost of fishermen is to buy diesel. The provision of diesel for fishermen, such as this program, aim to meet the supply of subsidized fuel for fishermen in parts scattered in coastal areas and small islands of Indonesia, especially at harvest time of fishing.

Programs of the government such as islands adoption program and SPDN have very good goal to empower the small islands community that most of the economically weak and development of natural resources, including renewable energy. However, there are some things that must be considered, that the government needs to ensure the sustainability of these programs, the accurate targeting of these programs and the benefits resulting from these programs. Continuity include community participation in the program, the availability of fuel supply and source of funding. 
People should have sense of belonging and the ability to run the program. Empowerment of women in the island adoption program is also very important because men generally easier to relocate for a new job (Nugroho 2012). Availability of supply must be guaranteed, because the petroleum reserves are running low. Government should be more alert and act decisively against hoarding and diversion of diesel distribution, ensure that diesel from SPDN only for fishermen in order to go to sea operations. The use of diesel fuel should be environmentally friendly, biodiesel can be accomplished. The use of kerosene should be bio-kerosene. Advantage of this program evaluation should be done continuously. Repairs and improvements based on community needs should be prioritized. CSR funding sources must be controlled and be used for the advancement of small islands. CSR is a source of capital funds to generate new revenue from community-based economic activities. Prioritizing domestic private companies is important, because sense of brotherhood and spirit of unity in diversity of Indonesia are still very need to be improved. Island adoption program can be a media to increase sense of unity of Indonesia. Transmigration program should be enhanced again. Many small islands that haven't utilized yet could be a transmigration area.

\subsection{Marine Microalgae as Sustainable Energy Resources}

Marine microalgae contain lipids that can be used as biofuel sources. Total content of oil and lipid in microalgae up to $70 \%$ of the dry weight. According Kawaroe et al. (2010) lipid content in microalgae is usually in the form of glycerol and fatty acids with chain lengths $\mathrm{C}_{14}$ to $\mathrm{C}_{22}$. They can be saturated or unsaturated. Types of biofuels that can be produced from marine microalgae among others bio-diesel and bio-kerosene. These biofuels are the most important fuel needs for people in outer and small islands for lighting, fishing, transportation and cooking. Biofuel can be produced from $100 \%$ marine microalgae or mixed with fossil fuels. This requires further research and development. The following images are some species of marine microalgae that can be used as biofuel sources.

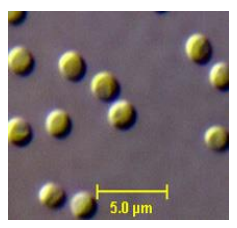

(a)

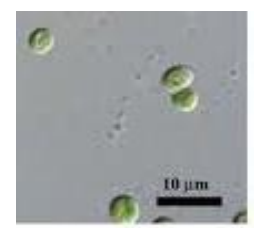

(b)

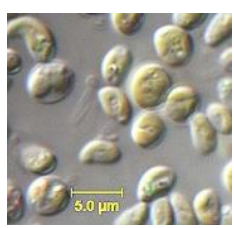

(C)

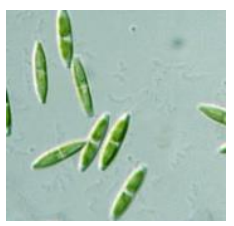

(d)

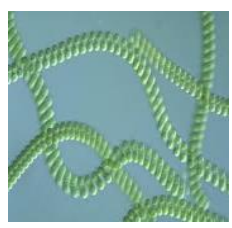

(e)
Fig. 1 Marine microalgae (a) Nannochloris sp. (b) Chlorella sp. (c) Nannochloropsis sp. (d) Nitzschia sp. (e) Spirulina sp. Source: http://cfb.unh.edu, http://www.biotekinstruments.ru, http://www.sb-roscoff.fr, http://protist.i.hosei.ac.jp, http://www.medon-solutio.cz

\subsubsection{Bio-diesel from marine microalgae}

According Kawaroe et al. (2010) the process of making biodiesel can be done as following. Microalgae are already harvested (by flocculation) from cultivation activities (raceway open ponds or photobioreactors) (for 4-7 days) are dried by oven at $200^{\circ} \mathrm{C}$. After that, the extraction process to take the rest of the remaining crude oil using soklet and solvent n-hexane for approximately 5-6 hours to obtain maximum results. Then, do the separation between crude oil and n-hexane solvent using a rotary evaporator and water bath. Next, crude oil was obtained get esterification and transesterification process using methanol and gas chromatography instrument with a flame ionization detector (GC-FID) to convert esters into methyl ester compounds (fatty acid methyl ester/FAME). After this process, the base material of biodiesel is obtained. This base material of biodiesel get washing process by adding $20 \%$ water to the base material and evaporation process by heating the base material of biodiesel that contain the water, until the water vapor point $\pm 112^{\circ} \mathrm{C}$ to produce biodiesel which clean from impurities.

\subsubsection{Bio-kerosene from marine microalgae}

Bio-kerosene requires the carbon chain to be shortened to about 12 , such as lauryl acids $\left(\mathrm{C}_{12: 0}\right)$. Some algae can produce short chain fatty acids with chain lengths $\mathrm{C}_{12}$ or $\mathrm{C}_{14}$, which can be methyl that is esterified to make bio-kerosene (Fude \& Tulip 2010). Biokerosene can used for aviation and cooking activities. 


\subsubsection{Advantages of marine microalgae as biofuel}

Marine microalgae have main advantage to be cultivated; the efficiency of taking water from the sea. Indonesia is very lucky because it has very wide sea, a lot of island and the total of coast line is very long and also has million peoples who live in coastal zone.

Generally, microalgae have advantages as biofuel that are:

- Compared to land plants, algae biomass processing costs are relatively cheaper, in addition, the biomass does not compete with this type of source food (Huang et al inside Hadiyanto 2013).

- Microalgae have a relatively rapid doubling time $(24$ hours) and have oil content ranged from 20-50\% with high productivity (Chisti 2007).

- Microalgae have the ability to assist in $\mathrm{CO}_{2}$ fixation and reduce the levels of $\mathrm{CO}_{2}$ in the atmosphere. Note that $1 \mathrm{~kg}$ of algal biomass requires $1.8 \mathrm{~kg}$ of $\mathrm{CO}_{2}$ (Chisti 2007).

- Microalgae produce primary products and byproducts are valuable such as high carbohydrate, protein, that can be used as a food supplements or feed for terrestrial animal and water animal (ex. fish) and also microalgae cultivation does not require herbicides (Rodolfi et al inside Hadiyanto 2013).

- The oil from microalgae extraction generally is neutral lipids and a weak saturated. This is an advantage for the manufacture of biodiesel (Danquah et al inside Hadiyanto 2013).

\subsection{Nusantara Microalgae Park as Solution}

Nusantara Microalgae Park is an integrated marine microalgae production area based on community to produce bio-diesel and bio-kerosene to face the declining petroleum reserves and global warming in Indonesia. This system is for the outer and small islands. By this system, outer and small islands can be more helpful with strong energy security also have an impact on reducing the population problem and strengthening national defense. The implementation of this strategy solution so that sustainable, there are four principles and five pillars. The principles are pro-poor, pro-job, pro-growth and pro-environment and the five pillars are economy, people, technology, academics and institutions coordination. This concept can be integrated with island adoption program, cooperative program and transmigration program.

\subsubsection{Principles}

Pro-Poor This principle is achieved by empowering citizens, community leaders, traditional leaders, local government in running the system through consultation, coaching, development, and evaluation together. This principle adapted to local wisdom and prevailing culture in the society. These are need to make the system still sustainable socially (Nugroho 2011). The meaning of the sustainable socially is building the awareness and social responsibility. Many governments renewable energy programs are stalled because of the lack of social sustainability (Nugroho 2011).

The unity between the components of the coastal communities will improve the welfare of the poor, because the local government will be closer to those people and knows their condition. Thus, the government becomes easier in implementing various welfare programs such as aid to its people in the form of venture capital and compensation. Basically, this principle is implementation of Pancasila that is populist. The implementation of Nusantara Microalgae Park increases the poor's income and prosperity.

Pro-Job This principle is achieved by opening new employment various professions and various education level includes researchers, teachers, extension agents, aquaculturist, security guards, environmentalists, energy experts, food scientists, industry entrepreneurs, exporters, drivers, fishermen, farmers, lawyers, economists, and experts-management of coastal and island. Thus, unemployment can be reduced. Graduates have an opportunity to work and people that could not finish the higher study can be work appropriate expertise and skills respectively. Basically, this principle is implementation of Pancasila that is the unity of Indonesia.

On February 2013, many people of Indonesia are unemployed/have not job up to 7,2 million people $(5,92 \%)$, they are graduates from elementary school and below $(3,61 \%)$, junior high school $(8,24 \%)$, senior high school $(8,39 \%)$, vocational high school $(7,68 \%)$, diploma I/II/III (5,65\%) and university (5,04\%) (Badan Pusat Statistik Republic of Indonesia 2013b).

Pro-Growth This principle is achieved by developing marine microalgae into various products that can generate new sources of revenue. This principle also promotes efficiency of microalgae biomass to be used as cyclical product or low waste even without waste product. Not only as product, but also activity of 
ecotourism in marine microalgae cultures area can be created from this system.

The various of product from marine microalgae cultivation such as bio-diesel, bio-kerosene, fertilizers and feed can produce income for local growth's such as infrastructure development. And then the ecotourism and edutourism from various places can produce the foreign exchange and retribution, these will push the local and national development. Basically, this principle is implementation of Pancasila that is social justice.

Pro-Environment This principle is achieved by generating cultivation activities that can absorb heavy metals, organic matter and carbon dioxide. Results of product development in the form of microalgae biofuels and byproducts like fertilizers and organic feed are environmentally friendly. Needs of water is efficient because they can get it from the sea. According to Fu-de \& Tulip (2010) by converting the flue gas from coalfired power stations and the $\mathrm{CO}_{2}$ emissions from mining into bio-diesel and bio-kerosene, microalgae can absorb almost all the carbon dioxide emitted from these sources so that the air becomes cleaner. And then microalgae have the ability to assist in $\mathrm{CO}_{2}$ fixation and reduce the levels of $\mathrm{CO}_{2}$ in the atmosphere. As note, $1 \mathrm{~kg}$ of algal biomass requires $1.8 \mathrm{~kg}$ of $\mathrm{CO}_{2}$ (Chisti 2007). The healthy environment will create the healthy people. This is the implementation of Pancasila that is humanity can be reached.

\subsubsection{Pillars}

Economy Sources of funding these activities can be sourced from CSR, national budget/local budget and community contributions are managed well. Funding from corporate social responsibility (CSR) aims to develop the potential of marine microalgae as a biofuel based on community empowerment. CSR funds can come from private companies and state-owned enterprises (SOEs). CSR funds are awarded to communities and it does not have to be returned. Funding from the state budget/local budget is a form of state responsibility to promote the general welfare and strengthening state sovereignty. Funding from the community contributions aims to increase the ownership sense of the business activities undertaken by community.

Institutions which consists of communities and village officials whose job to collect contributions from the community need to be formed. It could be a cooperative institution that is also currently being intensified again by the government. Cooperative is a populist form of business entity which is right for this system because it is based on kinship. Economic principle which is used is populist economic, which aims to promote the social and economic aspects of society to be more prosperous and independent.

People Society as the main actor; both as subject and object of the system. Awareness and the ability of communities is vital for functioning this system. Provision of human resources is done by transmigration, training, consulting, mentoring and evaluation with respect to local wisdom. According Kawaroe et al. (2010) the existence of coastal communities can help production development (culture activity) of marine microalgae extensively with water supply that is easily obtainable by taking from the sea. Through marine microalgae culture along the coast, especially in coastal areas that have not utilized as in outer and small islands, the production of marine microalgae in Indonesia will overflow so it can catch up other countries, such as the United States and Netherlands related to the development of marine microalgae.

Technology The technologies used include isolation technology of superior strains (pipette capillary method, serial dilution, subculture, scratches or antibiotics) (Kawaroe et al 2010), irrigation technology (distribution and change of sea water cultivation), cultivation technology (photobioreactors or raceway open pond) (Kawaroe et al 2010), harvesting technology, processing technology (extraction, esterification, transesterification, washing, etc.) (Kawaroe et al 2010) and marketing technologies (internet, network communications cooperative, coordination with company/state).

Academics The role of academics which includes university students, researchers, experts, technologists, lecturers, and instructors is very important in this system. University student's role in this system is to apply the knowledge gained in college and make this experience as a learning system for the provision of his life in the future. Role of researchers and technologists are to find a technology and media cultivation and processing of biofuels; system of public; and economic systems work better. The role of the experts are to provide suggestion and evaluation related to system running technically and theoretically. Lecturers role is to guide the students to be able to contribute to the system and share knowledge and discovery. Role of the 
instructors is to provide public education and policy related to how the system works and as community mentors. Coordination and unification science with experience between academics and the society is essential. Post of integrated society and academics (Pos masyarakat dan akademisi terpadu/Posmandu) will be formed to create better policy and integration.

Institutions Coordination Coordination between institutions such as local government, central government, PLN, Pertamina, cooperative of people, and Posmandu must be strong and caring to one another. It aims to be more united and without overlap in policy making.

\subsubsection{Implementation Strategy of Nusantara Microalgae Park}

Implementation strategy of Nusantara Microalgae Park includes the following steps. First, do the island spatial planning. Then do the feasibility study. The next, placement of the Navy as a pioneer. After that, the infrastructure development is done. Then the transmigration program is organized with the aim to outer and small islands. Furthermore, cooperatives and Posmandu is established. After that a series of activities which include isolation, cultivation, harvesting, conversion and marketing of marine microalgae as a biofuel is conducted. All are done in order to improve the national welfare and security.

Island spatial planning can be done in coordination by all relevant institutions such as Ministry of Public Works, Ministry of Maritime Affairs and Fisheries, Ministry of National Ddevelopment Planning, Statistics Central Agency (BPS), National Coordinating Body of Survey and Mapping (Bakosurtanal), as well as local government and public figure. Feasibility studies conducted by institutions such as the universities in the study of aspects of financing, location, product, marketing and development. Navy placement aims to improve the defense and accelerated development of the infrastructure. Transmigration was organized by the Ministry of Labor and Transmigration, if needed additional residents. Posmandu and cooperative are built by the community and academics. A series of activities which include isolation, cultivation, harvesting, conversion and marketing of marine microalgae as a biofuel are conducted by researchers, technologists, engineers, community and students.

\section{Conclusion}

Nusantara Microalgae Park can help government to increase the energy security in outer and small islands, also decrease the poverty and unemployment. The outer and small islands have potential and strategic role in national economic development and national defense. In addition, bio-diesel and bio-kerosene produced from this concept will very helpful for people in fishing and cooking environmentally friendly. Further research and development are required.

\section{Acknowledgements}

The authors are grateful to Allah SWT for the blessing and guidance to us. Thanks to our parents, our teachers and our friends for their support to us in writing this paper. Thanks to Forum for Scientific Studies (Forces) of Bogor Agricultural University and Scout Movement of Bogor Agricultural University that also support us.

\section{References}

Badan Pusat Statistik Republic of Indonesia. (2012) Jumlah dan Persentase Penduduk

Miskin, Garis Kemiskinan, Indeks Kedalaman Kemiskinan (P1), dan Indeks Keparahan Kemiskinan (P2) Menurut Provinsi, September 2012. http://www.bps.go.id/tab_sub/ view.php?kat= $1 \&$ tabel=1\&daftar=1\&id_subyek=23\&notab $=1$.

(2013a) Penduduk Berumur 15 Tahun ke Atas Menurut Jenis Kegiatan Tahun 2004 2013. http://www.bps.go.id/tab_sub/view.php?kat=1\&tabel= 1\&daftar=1\&id_subyek=06\&notab=1.

(2013b) Keadaan

Ketenagakerjaan Februari 2013. Berita Resmi Statistik No. 35/05/Th. XVI, 6 Mei 2013. http://www.bps.go.id/brs_file/ naker_06mei13.pdf.

Chisti, Y. (2007) Biodiesel from microalgae. Biotechnology Advances, 25, 294-306.

Christina, B. (2013) Cadangan Minyak Indonesia Anjlok. http://www.tempo.co/read/news/2013/01/30/090457860/Cad angan-Minyak-Indonesia-Anjlok.

Dahuri, R. (2003) Keanekaragaman Hayati Laut Aset Pembangunan Berkelanjutan Indonesia. Jakarta: Gramedia Pustaka Utama. (2005) Road Map Pembangunan Kelautan Nasional Menuju Indonesia yang Maju, Adil - Makmur dan Bermartabat. Inside: Aulia H.W. et al., Editor. Membangun Indonesia. Bogor: IPB Press. pp 45-73.

Directorate of Small Islands Utilization. (2012) Jumlah Pulau-Pulau Kecil. http://www.ppk-kp3k.dkp.go.id/.

Editorial Team. (2004) Pulau-Pulau Terluar Indonesia. Buletin DISHIDROS TNI AL. $1^{\text {st }}$ Edition/III.

Fu-de, Y. \& Tulip, R. (2010) Strategic path for the development of microalgal bio-diesel in China. http://rtulip.net/ yahoo_site_admin/assets/docs/Strategic_path_for_the_ 
development_of_microalgal_bio-diesel_in_China_-_August_ 2010.215180342.pdf.

General Directorate of Marine, Coastal and Small Islands. (2011) Adopsi Pulau. http://www.kp3k.kkp.go.id/index.php/content/ show/adopsi_pulau.

General Directorate of Oil and Gas. (2011) Statistik Minyak Bumi. http://www.esdm.go.id/minyak-bumi/produksi-konsumsiekspor-impor.html.

Hadiyanto. (2013) Valorisasi Mikroalga untuk Sumber Bioenergi dan Pangan sebagai Upaya Peningkatan Ketahanan Pangan dan Energi di Indonesia. http://call-for-papers.bappenas.go.id/papers/ Tema\%20IPTEK\%20hadiyanto_bappenas.pdf

Kawaroe, M., Prartono, T., Sunuddin, A., Sari, W.D. \& Augustine, D. (2010) Mikroalga Potensi dan Pemanfaatannya untuk Produksi Bio Bahan Bakar. Bogor: IPB Press.

Law of Republic of Indonesia No. 27 of 2007 on the Management of Coastal Areas and Small Islands.

Mawardi, M.I. (2009) Membangun Daerah yang Berkemajuan, Berkeadilan, dan Berkelanjutan. Bogor: IPB Press.
Mukhtar. (2009) Garis Pantai Indonesia Terpanjang Keempat di Dunia. http://www.kkp.go.id/index.php/arsip/c/1048/GarisPantai-Indonesia-Terpanjang-Keempat-di-Dunia/?category_id=

Nugroho, H. (2012) Energi dalam Perencanaan Pembangunan. Bogor: IPB Press.

Pikiran Rakyat Online. (2012) Akibat salah kelola, cadangan minyak RI tinggal 12 tahun. http://www.pikiran-rakyat.com/ node $/ 183564$.

Platmerah. (2013) Lepasnya Pulau Sipadan - Ligitan dari NKRI, karena Tak Ada Rupiah. http://platmerahonline.com/lepasnyapulau-sipadan-dan-ligitan-dari-nkri-karena-tak-ada-rupiah/.

Tempo. (2013) Pemerintah Bangun 1000 SPBU Solar buat Nelayan. http://www.tempo.co/read/news/2013/05/26/092483282/Pe merintah-Bangun1000-SPBU-Solar-buat-Nelayan.

United Nations Convention on the Law of the Sea 1982. 